\title{
TESTING THE QUALITY OF SPRAYING FLUID BY USING VARIOUS NOZZLES IN SPECIAL DEVICES LECHLER DROPLEG ${ }^{U L}$
}

\author{
Remigijus ZINKEVIČIUS, Institute of Agricultural Engineering and Safety, Faculty of Agricultural Engineering, Aleksandras \\ Stulginskis University, Studentu g. 15, Akademija, LT-53362 Kaunas raj., Lithuania, remigijus.zinkevicius@asu.lt (corresponding \\ author) \\ Sigitas ČEKANAUSKAS, Experimental Station, Aleksandras Stulginskis University, Studentu g. 15, Akademija, LT-53362 Kaunas \\ raj., Lithuania, sigitas.cekanauskas@ asu.lt
}

A variety of devices that help to prevent drops of spayed pesticides from getting into places that are difficult to reach (e. g. under the leaves of cultural plants of on the stem), is offered. Special devices Lechler Dropleg ${ }^{U L}$ are designed in a way that nozzles that are embedded in the end of the spraying pipe which is bended backwards, spray diagonally upwards.

Data of the quality of spraying fluid by using various sprinklers in special devices Lechler Dropleg ${ }^{U L}$ is provided in the article. Two hydraulic flood nozzles Lechler 684.356.30X, mounted in a special holder TwinSprayCap were examined: pneumohydraulic twin flat spray air-injector nozzle Lechler DF 120-03 and hydraulic twin flat spray nozzle Lechler DF 120-02. A transverse repartition and a process of the formation of fluid drops, sprayed using different nozzles were examined. The results revealed that while spraying with a lower working pressure (e.g. 1.5 bar) with two hydraulic flood nozzles Lechler $684.356 .30 \mathrm{X}$ that are placed in a special holder TwinSprayCap and embedded on a device Lechler Dropleg ${ }^{U L}$, a majority of drops (evenly around $40 \mathrm{ml}$ ) get into stand trays that are in a setting place situated $70-110 \mathrm{~cm}$ behind the device Lechler Dropleg ${ }^{U L}$, whereas at the approximate $40 \mathrm{~cm}$ area away from the setting place there are no drops of sprayed fluid at all. Having the working pressure increased to 3-4 bar, majority of drops (around $60 \mathrm{ml}$ ) get into the stend trays that are in a setting place situated $70-110 \mathrm{~cm}$ behind the device Lechler Dropleg ${ }^{U L}$. Having the working pressure increased, an unsprayed area, which is situated around the setting place of the device Lechler Dropleg ${ }^{U L}$, gets narrowed: a width of unsprayed area when spraying at the pressure of 2 bar was around $60 \mathrm{~cm}$, whereas when the pressure was 3 bar and 4 bar, the area appeared to be only $20 \mathrm{~cm}$. Circularly sprayed drops, depending on the working pressure, spread around in two strips of width from 1.4 to $1.8 \mathrm{~m}$. An oblong flat flow of the sprayed fluid forms nearby the deflector and the maximum height of the rise of sprayed drops reaches $1.3-1.4 \mathrm{~m}$.

Keywords: Special devices Lechler Dropleg ${ }^{U L}$, cross distribution of flood, nozzles.

\section{INTRODUCTION}

With an intention for as much drops of protective fluids for sprayed plants as possoble to reach the surfaces of plants that are being collected, additional devices Dropleg are offered to conventional hydraulic field sprayers. Those are special bended spraying pipes, designed for spraying pesticides under the leaves of cultural plants.

Depending on the construction and area of use of the devices Dropleg, only one nozzle can be used on them (at the end of bended spraying pipe) or a couple of nozzles can be used if attatched in different heights. Fluid is sprayed into separate directions, most commonly from bottom to top, however, in some cases it can be directed downward. The most significant advantage of this equipment is that fungicide and insecticide get into places that are rather difficult to reach, for example, under the leaves of cultural plnts or on the branches that are close to the ground (Rüegg et al., 2013).

The performed analysis of information sources shows that special devices that are used to spray under the leaves of cultural plants are successfully used in the crops of various vegetables, potatoes, rape, corn, and sugar beet.

In Lithuania the tests of using devices Lechler Dropleg ${ }^{U L}$ were carried out in potato crops. It has been estimated that when using special devices Lechler Dropleg ${ }^{U L}$ with flood nozzles Lechler FT 1.0 in the early stages of the growth of the potatoes and spraying from the top with multirange flat spray nozzle $L U-120-02$, the stems of the potatoes and the bottom of the leaves that are at the top of the plants were covered in a more consistent way. When using this equipment in the later stages of the growth of the potatoes, only the bottom of the leaves that are at the top of the plants was covered in a more consistent way. The differences of the area of sprayed surfaces are minor when embedding twin flat spray nozzles Lechler DF-120-02, in the devices Lechler Dropleg ${ }^{U L}$ and multirange flat spray nozzle $L U-120-02$ in the holders of the girder of the sprayer (Šniauka and Zinkevičius, 2015).

The performance of the specific equipment for spraying under the leaves was investigated in organically grown potato crops in Germany (Irla et al, 2000; Irla et al, 2001; Neuhoff et al, 2002).

German researchers Irla E., Anken T. and Krebs H. identified that in organically grown potato crops the optimal liquid spraying rate is $400-500$ 1/ha and work pressure from 7 till $10 \mathrm{bar}$, while the ground speed of spraying equipment

Copyright (C) 2017 The Authors. Published by Aleksandras Stulginskis University. This is an open-access article distributed under the terms of the Creative Commons Attribution License (CC-BY 4.0), which permits unrestricted use, distribution, and reproduction in any medium, provided the original author and source are credited. 
is $4-5 \mathrm{~km} / \mathrm{h}$. Coverage of the surfaces sprayed improves using additional air systems, injector type hydro-pneumatic nozzles and equipment for spraying under the leaves (Irla et al, 2000).

In two-year investigation, Irla E., Anken T., Krebs H. and Ruegg J. compared technologies for spraying copper preparations in organically grown potato crops (Agria species). It was identified, that using specific equipment for spraying under the leaves, potato leaves, first of all their underside, were better covered with the copper preparation. After increasing the spraying rate from 400 till 500 1/ha, the coverage of potato leaves increased from 4 till 37 percent. Both, the first and second, year of investigations did not disclose essential differences between the alternatives (hydraulic field sprayer with injector type hydro-pneumatic nozzles vs specific equipment for spraying under the leaves) of reducing the amount of leave rot. The authors of the article did not deliver any data on potato productivity. However, they believe that the consumption of copper preparations sprayed using specific equipment for spraying under the leaves 400-500 1/ha can be reduces by approx. 50 percent. (Irla et al, 2001) on organically grown potato crops.

Neuhoff D., Klinkenberg H.- J. and Köpke U. used Jacoby hydraulic field sprayer equipped with the specific equipment for spraying under the leaves and aggregated with Hege tractor in their experiments. Pesticides were sprayed using hydraulic slit nozzles. The investigations showed that maximum possible coverage of the underside of leaves of cultural plants is especially important in organic farming. It was identified that potato leave rot can be reduced by 50 percent spraying in a usual manner (i.e. downwards) and upwards (using specific equipment for spraying under the leaves). However, the results of spraying the other preparations were controversial (Neuhoff et al, 2002).

Roeb J. and Bernhardt $\mathrm{H}$. have estimated that conventional hydraulic field sprayers with multirange flat spray nozzles $L U-120-02$ are not suitable anymore to spray herbicides in the later stages of the growth of sugar beet. The quality of spreading herbicides over the crops of sugar beet improves when using hydraulic twin flat spray nozzles Lechler DF 120-02, however, the best results were registered when using devices to spray under the leaves of cultural plants. It is important that the leaves of sugar beet would grow at a sharp angle from the vertical and row spacing would not be covered yet (Roeb and Bernhardt, 2013).

The purpose of the research is to measure the changes and the quality of the process of spraying fluids by using special devices Lechler Dropleg ${ }^{U L}$ that are designed for spraying under the leaves of cultural plants while using different nozzles.

\section{OBJECT AND METHODS}

Special devices Lechler Dropleg ${ }^{U L}$ with different nozzles are the object of the research. The research was carried out from 2012 to 2014 in the Institute of Agricultural Engineering and Safety (Aleksandras Stulginskis University). The research was repeated three times. The stand (Figure 1) which is designed to assess the transversal distribution of sprayed fluids consists of a gear, pump, mixer, fluid container, remote control, fluid serving bowel, filters, distribution pipe, nozzles, trays, and cruets to gather the fluid.

When estimating the transversal distribution, fluid was sprayed using one or two nozzles on the trays that were of $100 \mathrm{~mm}$ width, $130 \mathrm{~mm}$ height, and $1.5 \mathrm{~m}$ length. General width of the stands $1.5 \mathrm{~m}$. The fluid flowed in the trays towards the fluid gathering cruets $(500 \mathrm{ml})$ that were graduated every $10 \mathrm{ml}$. Error of the amount of the fluid is $\pm 10 \mathrm{ml}$. During the action of spraying an optimal working pressure noted by the manufacturer is estimated (1.5, 2, 3 and 4 bar). The device Lechler Dropleg ${ }^{U L}$ was assembled above the trays of the stand.

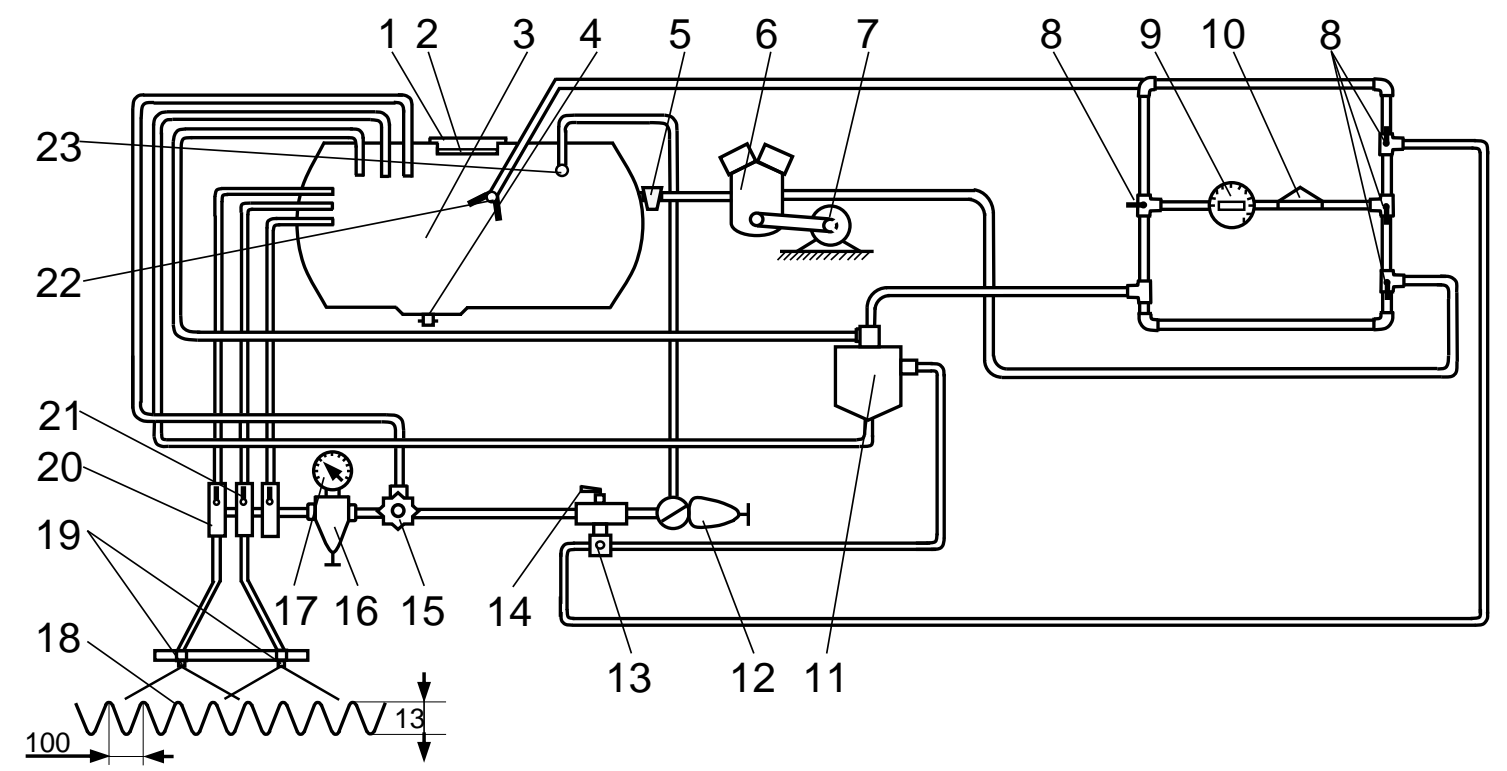

Figure 1. The scheme of test stand: 1 - filler; 2 - filler filter; 3 - tank; 4 - outlet tap; 5 - suction line filter; 6 - pump; 7 - electromotor; 8 three-way taps; 9 - flowmeter; 10 - filter; 11 - pressure lines filter; 12 - reducer valve; 13 - mixer on/off tap; 14 - closing tap; 15 - throttle; 16 - filter; 17 - manometer; 18 - troughs; 19 - nozzles; 20 - control sections taps; 21 - throttles; 22 - hydraulic mixer; 23 - safety-valve. 
Two hydraulic flood nozzles Lechler $684.356 .30 \mathrm{X}$ that were embedded in a special holder TwinSprayCap, pneumohydraulic twin flat spray air-injector nozzle Lechler IDKT 120-03, and hydraulic twin flat spray nozzle Lechler DF 120-02 were examined (Figure 2).

$\mathbf{a}$

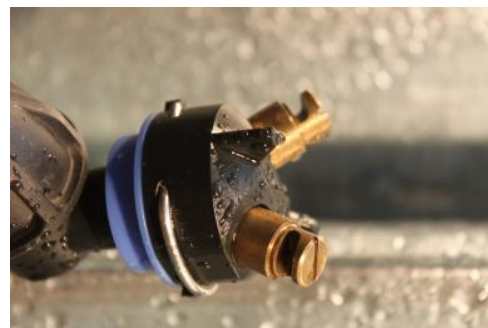

b

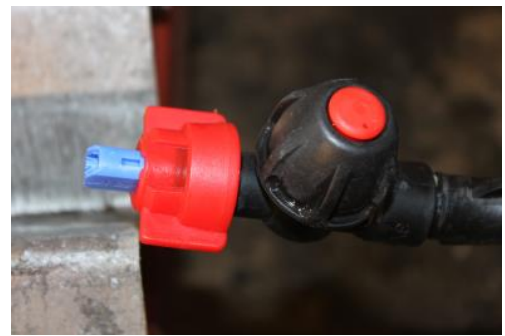

c

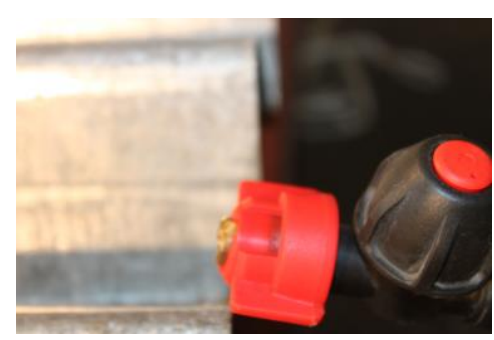

Figure 2. Images of the examined nozzles that are embedded in the device Lechler Dropleg ${ }^{U L}: \mathrm{a}-$ two hydraulic flood nozzles Lechler 684.356.30X; b - one pneumohydraulic twin flat spray air-injector nozzle Lechler IDKT 120-03; c - one hydraulic twin flat spray nozzle Lechler DF 120-02

The flow of drops sprayed through the nozzles embedded on the device Lechler Dropleg ${ }^{U L}$ was filmed with a highspeed camera FASTCAM 1024PCI which can take from 60 to 109500 shots per second. In this case the frequency was 1000 shots per second.

\section{RESULTS AND DISCUSION}

When examining the transversal distribution of fluids sprayed through two hydraulic flood nozzles Lechler 684.356.30X which were embedded in the special holder TwinSprayCap on the device Lechler Dropleg ${ }^{U L}$, we noticed (figure 3) that spraying when using a lower working pressure, for example, $1.5 \mathrm{bar}$, at the approximate area of $40 \mathrm{~cm}$ (between 18 and 19 cruets) causes no appearance of drops of the sprayed fluid. In this case the majority of drops (40ml) gets to the trays that are 70-100 cm away from the setting place of the device Lechler Dropleg ${ }^{U L}$. Roundly sprayed drops distribute in two areas that are of $1.4 \mathrm{~m}$ width when sprayed through two hydraulic flood nozzles Lechler 684.356.30X which were embedded in the special holder TwinSprayCap on the device Lechler Dropleg ${ }^{U L}$ (figure 3).

With the increase of working pressure, narrows the non-sprayed area around the setting place of the device Lechler Dropleg $^{U L}$. When spraying at 2 bar working pressure with two hydraulic flood nozzles Lechler 684.356.30X embedded in the holder TwinSprayCap, the non-sprayed area was around $60 \mathrm{~cm}$, whereas when the pressure was 3 bar and 4 bar, the area covered only $20 \mathrm{~cm}$. When spraying at 2 bar working pressure, most of the drops (around $63.3 \mathrm{ml}$ ) get to the stand trays that are $90 \mathrm{~cm}$ behind the setting place of the device Lechler Dropleg ${ }^{U L}$. The drops distribute in the two areas that are of $1.5 \mathrm{~m}$ width (Figure 3).

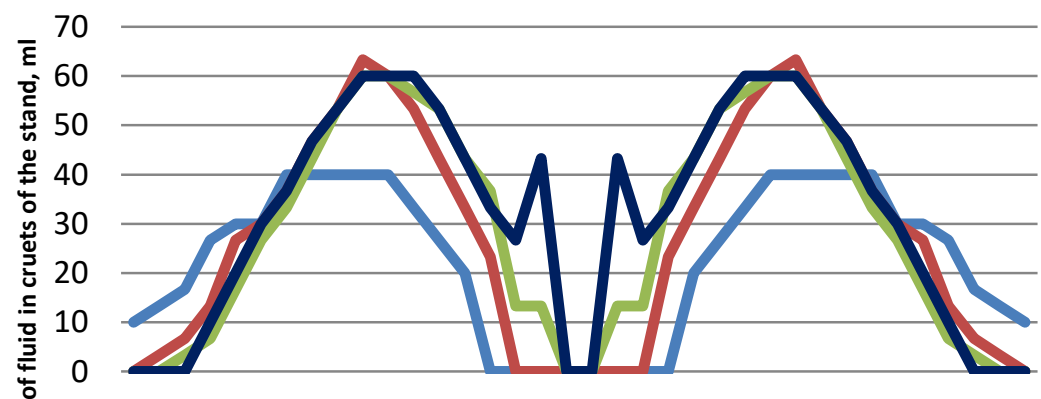

$\begin{array}{llllllllllllllllll}1 & 3 & 5 & 7 & 9 & 11 & 13 & 15 & 17 & 19 & 21 & 23 & 25 & 27 & 29 & 31 & 33 & 35\end{array}$

number of the cruet of the stand

1,5 bar 2 bar 2 bar $\rightleftharpoons 4$ bar

Figure 3. Transversal distribution of fluids, sprayed by two hydraulic flood nozzles Lechler 684.356.30X that are embedded in the special holder TwinSprayCap on the device Lechler Dropleg ${ }^{U L}$ at a different working pressure

When the working pressure is $3 \mathrm{bar}$, most of the drops $(60 \mathrm{ml})$ get to the stand trays that are $80-90 \mathrm{~cm}$ behind the setting place of the device Lechler Dropleg ${ }^{U L}$. The drops distribute in the two areas that are of $1.8 \mathrm{~m}$ width (figure 3 ).

When spraying at a working pressure of 4 bar with two hydraulic flood nozzles Lechler 684.356.30X that are embedded in a special holder TwinSprayCap, most of the drops $(60 \mathrm{ml})$ get to the stand trays that are $70-90 \mathrm{~cm}$ behind the setting place of the device Lechler Dropleg ${ }^{U L}$. The drops distribute in the two areas that are of $1.4 \mathrm{~m}$ width (figure 3 ).

During the examination of transversal distribution of fluids sprayed through pneumohydraulic twin flat spray airinjector nozzle Lechler IDKT 120-03 we noticed (figure 4) that most of the drops (110-183 ml, depending on working 
pressure) get to the stand trays that are next to the setting place (between 12 and 13 cruets) of the device Lechler Dropleg ${ }^{U L}$. The most significant amount of fluid, in this case, is sprayed in the areas from $10 \mathrm{~cm}$ (working pressure $1.5-2$ bar) to 20 $\mathrm{cm}$ (working pressure 3 and 4 bar). Generally speaking, drops, sprayed with the nozzle embedded on this device Lechler Dropleg ${ }^{U L}$ distribute in areas (figure 4) from $1.8 \mathrm{~m}$ (working pressure 4 bar) to $2.1 \mathrm{~m}$ (working pressure 1.5 and 2 bar). It can be seen that the transversal distribution of fluid sprayed through pneumohydraulic twin flat spray air-injector nozzle Lechler IDKT 120-03 embedded on the device Lechler Dropleg ${ }^{U L}$ is not ideally symmetrical when the working pressure is different.

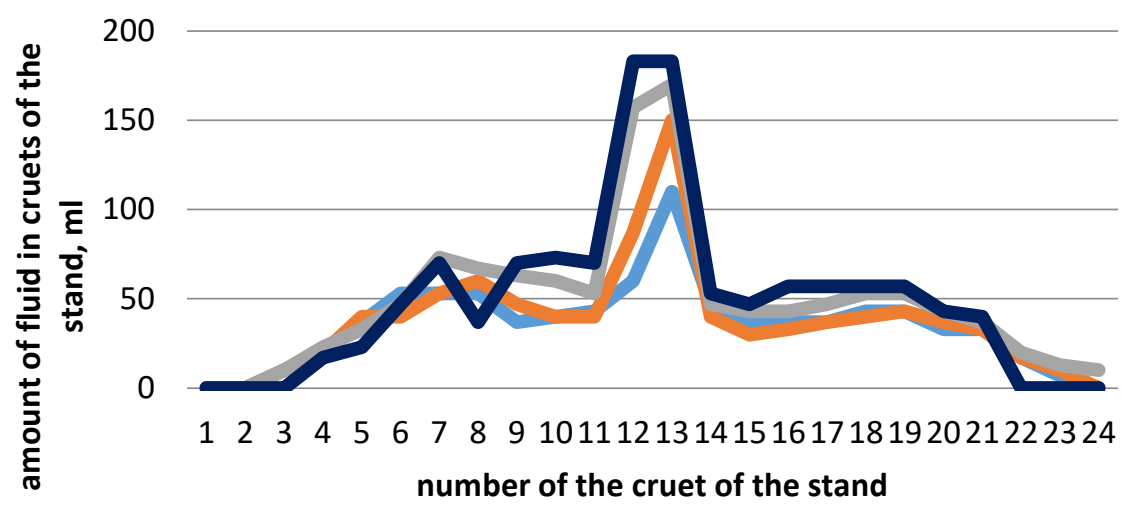

1,5 bar 2 bar 3 bar $\rightleftharpoons 4$ bar

Figure 4. Transversal distribution of fluids, sprayed through pneumohydraulic twin flat spray air-injector nozzle Lechler IDKT 120 03 embedded on the device Lechler Dropleg ${ }^{U L}$ at a different working pressure

The tests that have been carried out show that when spraying through a hydraulic twin flat spray nozzle Lechler DF 120-02 embedded on the device Lechler Dropleg ${ }^{U L}$, most of the drops get to the stand trays that are 30-50 cm away from the setting place (between 12 and 13 cruets) of the device Lechler Dropleg ${ }^{U L}$ (Figure 5).

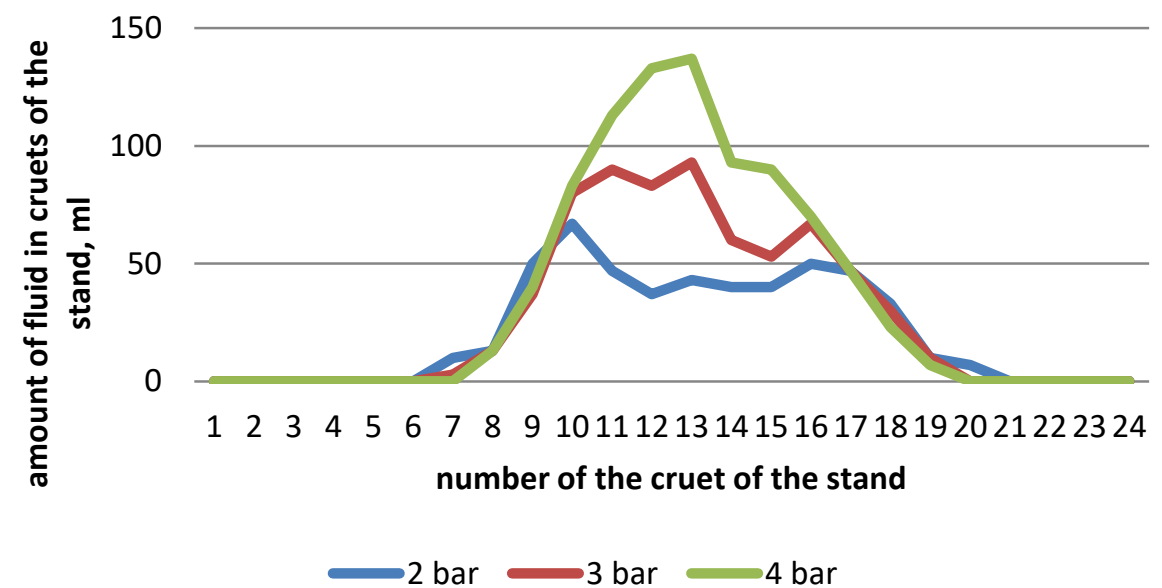

Figure 5. Transversal distribution of fluids, sprayed through twin flat spray nozzle Lechler DF 120-02 embedded on the device Lechler Dropleg ${ }^{U L}$ at a different working pressure

When the working pressure increases, a plentifully sprayed area that is around the setting place of the device Lechler Dropleg $^{U L}$ narrows. When spraying through a hydraulic twin flat spray nozzle Lechler DF 120-02 embedded on the device Lechler Dropleg ${ }^{U L}$ at 2 bar working pressure, more plentifully (33-67 ml) sprayed area was of a size of $1 \mathrm{~m}$, whereas when the working pressure was 3 bar it was only $70 \mathrm{~cm}$. When spraying at 4 bar working pressure, more fluid got to the trays that are in the setting place of the device Lechler DroplegUL than it was when the working pressure was 2 bar (Figure 5).

When analysing images (of fluids sprayed through the above mentioned nozzles) caught on the high-speed camera FASTCAM 1024PCI it is clear that a flow of differens shape forms next to the nozzle. When spraying through the hydraulic flood nozzle Lechler 684.356.30X, an oblong flat flow of sprayed fluid is formed (figure 6), whereas when using pneumohydraulic twin flat spray air-injector nozzle and hydraulic twin flat spray nozzle, the flow is rather small and more rounded (Figures 7). 


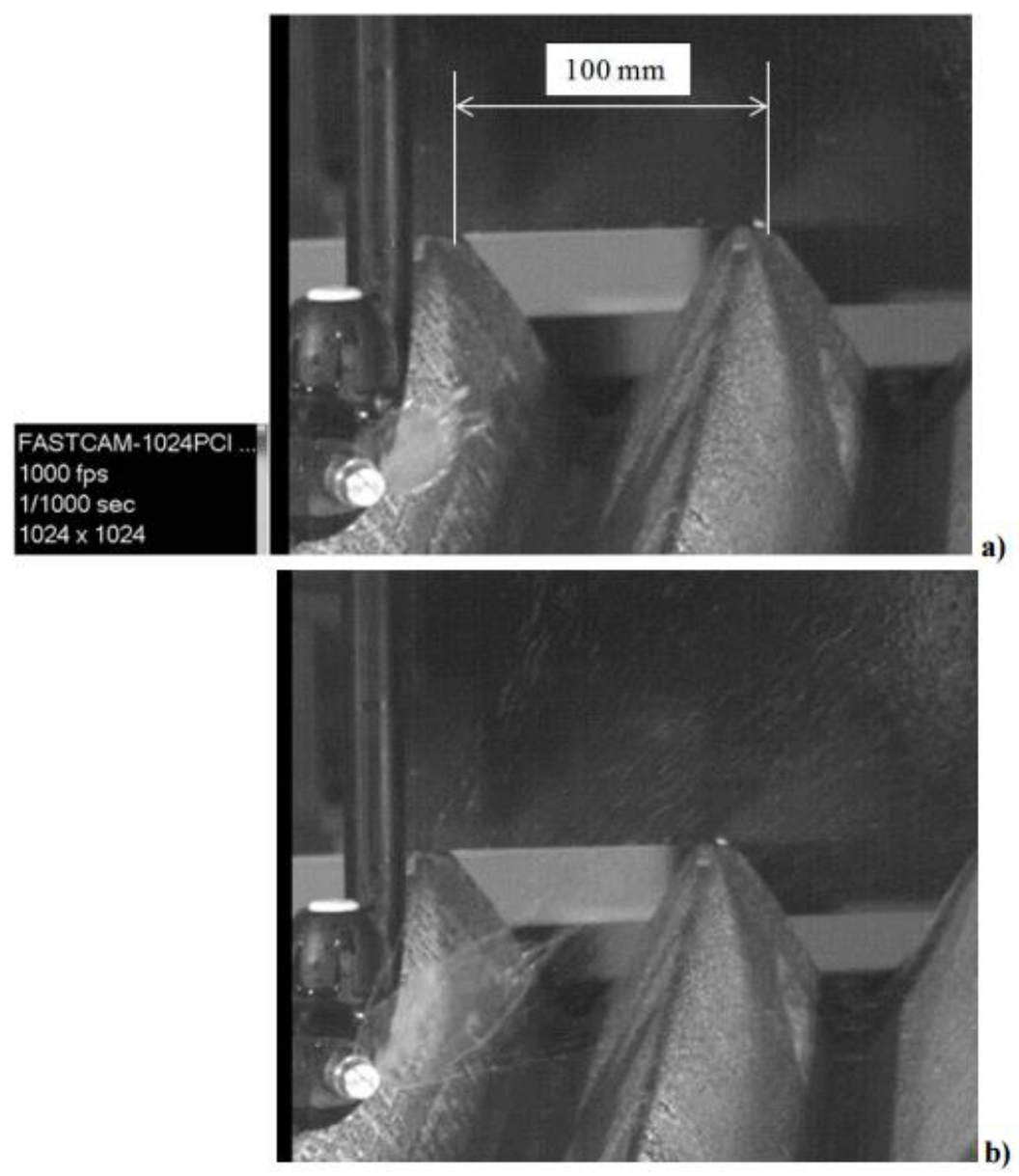

Figure 6. Front images of flow of the fluids sprayed through hydraulic flood nozzle Lechler 684.356.30X that is embedded in a special holder TwinSprayCap on the device Lechler Dropleg ${ }^{U L}$ : a - flat flow at the beginning of spraying; $\mathrm{b}$ - flat flow split into drops

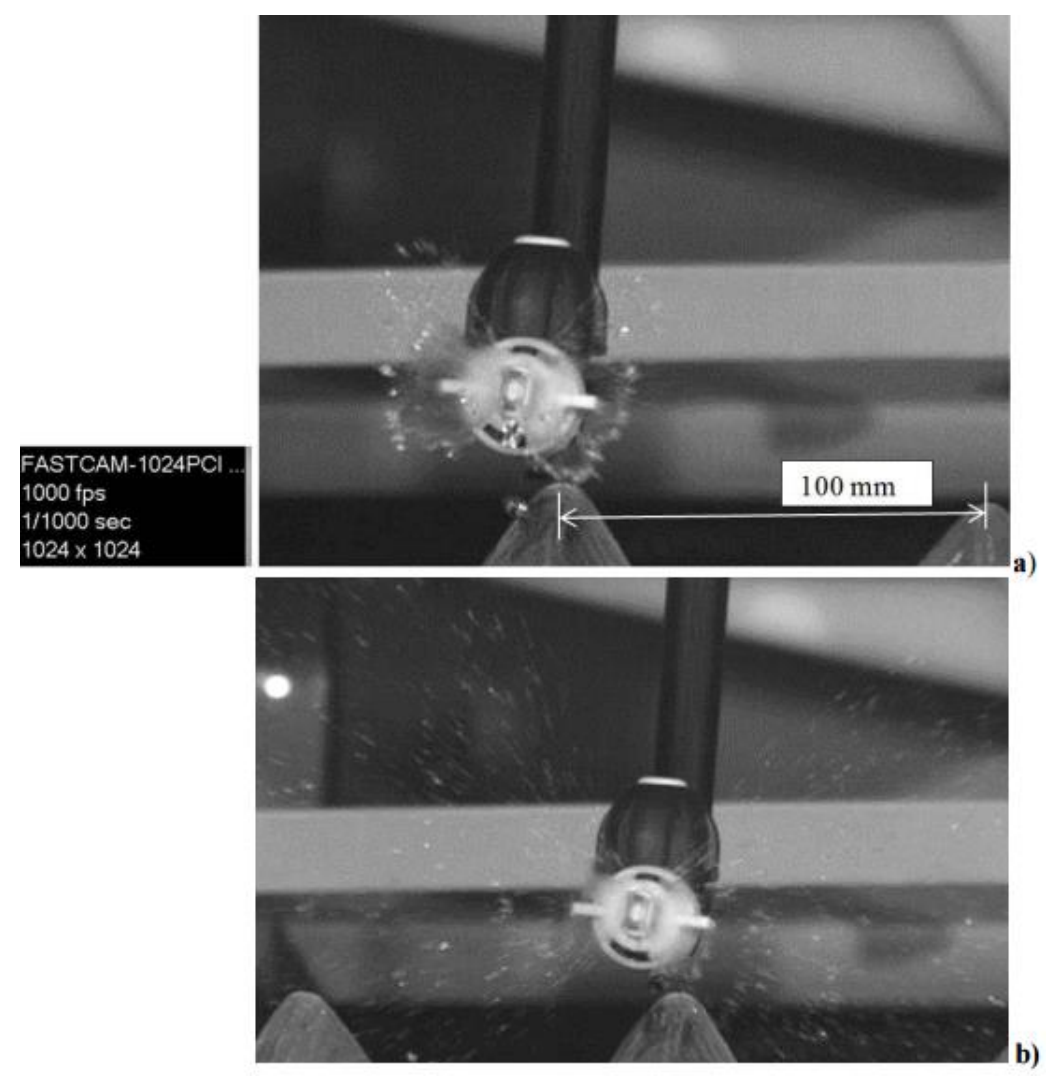

Figure 7. Front images of flow of the fluids sprayed through pneumohydraulic twin flat spray air-injector nozzle Lechler IDKT 12003 that is embedded on the device Lechler Dropleg ${ }^{U L}$ : a - two flat flows at the beginning of spraying; $\mathrm{b}$ - flat flows split into drops 
The research has shown that the maximum height of the rise of drops sprayed through different nozzles differs. The drops sprayed through twin flat spray nozzle Lechler DF 120-02 at a 2-4 bar working pressure rose up only 0.6-0.8 $\mathrm{m}$, whereas the height was $0.7-1.0 \mathrm{~m}$ when spraying through pneumohydraulic twin flat spray air-injector nozzle and even 1.3-1.4 m when using hydraulic flood nozzle.

\section{CONCLUSIONS}

1. Having performed the tests of two hydraulic flood nozzles Lechler 684.356.30X that are embedded in the special holder TwinSprayCap on the device Lechler Dropleg ${ }^{U L}$, a conclusion can be drawn that:

- when spraying at a lower working pressure (e.g. $1.5 \mathrm{bar})$, the majority of drops $(40 \mathrm{ml})$ get to the stand trays that are $70-110 \mathrm{~cm}$ away from the setting place of the device Lechler Dropleg ${ }^{U L}$, whereas the area further than $40 \mathrm{~cm}$ away from the setting place has no signs of drops at all. When the working pressure is increased up to $3-4$ bar, the majority of drops $(60 \mathrm{ml})$ get to the stand trays that are $70-90 \mathrm{~cm}$ away from the setting place of the device Lechler Dropleg ${ }^{U L}$;

- when the working pressure is increased, the non-sprayed area around the setting place of the device Lechler Dropleg $^{U L}$ is narrowed: the non-sprayed area was $60 \mathrm{~cm}$ when the pressure was 2 bar, but when it was 3 and 4 bar, the area was only $20 \mathrm{~cm}$;

- $\quad$ roundly sprayed drops depending on working pressure distribute in two areas of 1.4-1.8 m width;

- an oblong flow of sprayed fluid forms next to the deflector and the maximum height of the rise of the drops is up to $1.3-1.4 \mathrm{~m}$.

2. The tests of pneumohydraulic twin flat spray air-injector nozzle Lechler IDKT 120-03 embedded on the device Lechler Dropleg ${ }^{U L}$ show that:

- the majority of drops (110- $183 \mathrm{ml}$ depending on working pressure) get to the stand trays that are next to the setting place of the device Lechler Dropleg ${ }^{U L}$;

- the most significant amount of fluid is sprayed in the areas from $10 \mathrm{~cm}$ (working pressure 1.5 and 2 bar) to 20 (working pressure 3 and 4 bar) $\mathrm{cm}$;

- roundly sprayed drops distribute in the areas from $1.8 \mathrm{~m}$ (working pressure 4 bar) to $2.1 \mathrm{~m}$ (working pressure 1.5 and 2 bar);

- the transversal distribution of sprayed fluid at a different working pressure is not ideally symmetrical;

- a small and rounded field of sprayed fluid forms next to the nozzle and the maximum height of the rise of the drops is $0.7-1.0 \mathrm{~m}$.

3. The tests of hydraulic twin flat spray nozzle Lechler DF 120-02 embedded on the device Lechler Dropleg ${ }^{U L}$ show that:

- $\quad$ the majority of drops get to the stand trays that are next to the setting place of the device Lechler Dropleg ${ }^{U L}$;

- when the working pressure is increased, the more plentifully sprayed area around the setting place of the device Lechler Dropleg ${ }^{U L}$ is narrowed: the width of the more plentifully sprayed area $(33-67 \mathrm{ml})$ was approximately $1 \mathrm{~m}$ when the pressure was $2 \mathrm{bar}$, when it was 3, the the width was $80 \mathrm{~cm}$ and at the pressure of 4 bar the width of the area was only $70 \mathrm{~cm}$;

- when spraying at a 4 bar working pressure, over three times more fluid got into the trays situated next to the setting place of the device itaiso Lechler Dropleg ${ }^{U L}$ than it got there when the pressure was 2 bar;

- the transversal distribution of sprayed fluid at a different working pressure is not ideally symmetrical;

- small and rounded flow of the sprayed fluid forms next to the nozzle and the maximum height of the rise of the drops is only $0.7-0.8 \mathrm{~m}$.

\section{REFERENCES}

1. Irla, E., Anken, T., Krebs, H. 2000. Application technique for phytophtora control in organic potato cultivation, In: IFOAM 2000: the world grows organic. Proceedings 13th International IFOAM Scientific Conference, Basel, Switzerland, Hochschulverlag AG an der ETH Zürich, 28-31 August, 2000.

2. Irla, E, Anken, T., Krebs, H, Rüegg, J. 2001. Optimierung der Spritztechnik in Biokartoffeln. Neue Technik erfolgreicher gegen Krautfäule. FAT-Berichte Nr. 561, Eidgenössische Forschungsanstalt für Agrarwirtschaft und Landtechnik, Tänikon, s. 1-8. [In Germany].

3. Neuhoff, D., Klinkenberg, H.-J., Köpke, U. 2002. Kartoffeln im Organischen Landau: Bekämpfung der Kraut- und Knollenfäule (Phytophtora infestans (Mont.) De Bary). Landwirtschaftliche Fakultät der Universität Bonn, Schriftenreihe des Lehr- und Forschungsschwerpunktes USL, Nr. 89, 76 S. [In Germany].

4. Roeb, J., Bernhardt, H. 2013. Applikationsverfahren gegen die Restverunkrautung in Zuckerrüben. Landtechnik, No. 68 (3), pp. 187-191. [In Germany].

5. Šniauka, P., Zinkevičius, R. 2015. Investigations of Applying Biological Product biokal1 on Potato Crops with Specific Equipment Lechler Dropleg ${ }^{\mathrm{UL}}$ for Spraying under the Leaves of Cultural Plants. Proceedings of the 7th International Scientific Conference Rural Development 2015, pp. 1-5. 19-20 November 2015, Aleksandras Stulginskis University. $\underline{\text { https://doi.org/10.15544/RD.2015.019. }}$ 